\section{Hrvoje Gržina}

Hrvatski državni arhiv, Zagreb

Izvorni znanstveni rad / Original scientific paper

UDK / UDC: 77 Pommer, F.

18. 6. 2014.

\title{
Dopuna životu i radu Franje Pommera, prvoga rezidentnog zagrebačkog fotografa
}

Ključne riječi: Franjo Pommer, Zagreb, fotografski atelje, slani papir, albuminska fotografija, karbonska fotografija Keywords: Franjo Pommer, Zagreb, photographic studio, salted paper print, albumen print, carbon print

U ovom su radu na jednom mjestu izložene dosadašnje, a pridodane su i neke nove spoznaje vezane uz rad fotografa Franje Pommera. Osim što je ostao zabilježen kao prvi zagrebački rezidentni fotografski majstor te autor prvoga zaokruženog fotografskog projekta zamišljenog i izvedenog u Hrvatskoj, značajan je i po uvođenju određenih noviteta u standardnu fotografsku praksu. Tekst u proom dijelu donosi dopunjeni pregled Pommerove biografije nastao na osnovi proučavanja arhivskog gradiva i periodike, a u drugom se, analizirajući sačuvane primjerke, osvrće na tehniku izrade fotografija i formate snimki koje je majstor u svome radu koristio, precizno ih određujući te usklađujući nazivlje sa suvremenom terminologijom.

\section{Uvodno zapažanje}

Život i rad prvoga stalnog zagrebačkog fotografa, Franje Pommera, dosad je istraživan i obrađivan u više navrata i kroz nekoliko publikacija. Ponajprije valja istaknuti kapitalni rad Nade Grčević Fotografija devetnaestog stoljeća u Hrvatskoj u kojem je Pommeru posvećeno punih devetnaest stranica, a potom i prezentaciju odabranih autorovih radova 1994. godine na velikoj izložbi Fotografija u Hrvatskoj 1848-1950 održanoj u Muzeju za umjetnost i obrt u Zagrebu. U pripadajućem je katalogu reproducirano nekoliko njegovih fotografija, a nije izostavljen ni na izložbi Historicizam u Hrvatskoj, priređenoj u istom muzeju 2000. godine. Tom je prigodom izloženo i u popratnom katalogu reproducirano pet Pommerovih snimaka. Također je, uz više ili manje detalja, spomenut u gotovo svim objavljenim sintezama hrvatske fotografske povijesti, kao i u većini radova vezanih uz hrvatsku fotografiju ranog razdoblja, a osnovne je podatke o njegovu radu moguće naći i na više mrežnih stranica. $\mathrm{Na}$ tim je temeljima izraslo istraživanje kojim su izmijenjeni i dopunjeni određeni segmenti fotografove biografije, kao i pojašnjeni neki detalji vezani uz fotografsku tehniku i procese koje je koristio.

Dvadesetpetogodišnji rad Franje Pommera u Zagrebu najvećim je dijelom bio vezan uz fotografski atelje i danas su - uz tek pokoju fotografiju i nekoliko vijesti o snimanju na terenu - ostale sačuvane gotovo isključivo portretne snimke. One bilježe mnoge istaknute pojedince iz političkog, kulturnog i javnog života Hrvatske u drugoj polovini 19. stoljeća kao i pripadnike građanske klase, koji su u Pommerovu ateljeu, upravo poradi visoke izvedbene vrijednosti snimaka te kontinuiranog praćenja noviteta na području fotografske tehnologije, prepoznali rad provjerenog i nagradama potvrđenog majstora s osobitim ugledom u onodobnom hrvatskom društvu.

\section{Dopunjeni životopis}

Franjo Pommer rođen je 1818. godine u Danskoj. ${ }^{1}$ Sačuvani izvori govore kako je u Zagreb došao najkasnije 1852. godine i zaposlio se kao dekorater u kazalištu. ${ }^{2}$ Dvije godine kasnije 
novine ga, zajedno s Josephom Kallainom, spominju kao suvlasnika fotografskog ateljea u gornjogradskoj Vijećničkoj ulici kbr. 10 (danas Kuševićeva ulica) u kojem je snimljen uspješan portret primadone Kammerer. ${ }^{3}$ Spomenuti napis predstavlja najraniji poznati podatak o adresi Pommerova zagrebačkog ateljea.

Sljedeća je vijest o njemu objavljena u Narodnim novinama 1855. godine i govori kako Pommer namjerava izdati album s portretima petnaestorice književnika uz pridodane njihove životopise. ${ }^{4} \mathrm{U}$ istom je tekstu zabilježen i podatak kako je za taj pothvat nabavio i skupi »stroj fotografički, što ga sastavi Weingartshofen u Döblingu kod Beča.$^{5}$ Ova je vijest poslije u hrvatskoj literaturi djelomice pogrešno protumačena te je, mada je ispravljeno pogrešno navedeno ime proizvođača fotografske opreme, krivim povezivanjem plasirana informacija kako je Pommerova kamera konstruirana u Mödlingu kraj Beča. ${ }^{6}$ Kraće istraživanje povijesti austrijske fotografije u tom je kontekstu uputilo na nekoliko pogrešaka, što u samom tekstu u novinama što u kasnijoj interpretaciji kroz literaturu. Prije svega, ispravno prezime konstruktora je Weingartshofer, a ne Weingartshofen, kako stoji u citiranom tekstu iz Narodnih novina. Nadalje, uz navedeno ime proizvođača nije vezana konstrukcija kamere nego samo fotografskog objektiva - proizvedenog u Beču - na sačuvanim primjercima kojeg ugravirano stoji » Weingartshofer in Wien, Oberdöbling No. 234 «. ${ }^{7}$ Riječ je o proizvodu bečkog fotografa i optičara Mathiasa Weingartshofera, izrađivanom sredinom 1850-ih godina u Döblingu - vidljivo je kako je Pommer investirao u najnoviju dostupnu opremu - kao što je autor teksta u Narodnim novinama ispravno prenio, vjerojatno misleći kako se naziv proizvođača objektiva postavljenog na kameru odnosi na cijeli aparat. Konačno, očito je i kako je na osnovi sačuvanih fotografija došlo do poistovjećivanja već spomenutog Mathiasa Weingartshofera koji se, osim kroz fotografsku karijeru, u Döblingu osobito afirmirao radeći kao optičar, fotopublicist i stručni autor, s njegovim sinom Carlom Weingartshoferom, također fotografom, koji je u Mödlingu kraj Beča vodio fotografski studio. ${ }^{8}$ Navedene su se pogreške zadržale u publikacijama o hrvatskoj fotografiji sve do danas.

Spomenutim je objektivom i njemu pridruženom kamerom Pommer započeo rad na fotografskom pothvatu po kojem će ostati osobito zapamćen u povijesti hrvatske fotografije. Među portretiranim književnicima tako su se našli: Vjekoslav Babukić, Mirko Bogović, Dimitrija Demeter, Ivan Kukuljević Sakcinski, Bogoslav Šulek, Ljudevit Vukotinović, Ljudevit Gaj, Antun i Ivan Mažuranić, Petar Preradović, Pavao Štoos i Ivan Trnski. Uz njih bilo je planirano priložiti i portrete tada već preminulih Dragutina Rakovca i Stanka Vraza, dok ime petnaestog pisca, koje u novinama nije spomenuto, treba tražiti između »drugih živućih naših vèrlih književnikah, koje će on do malo snimiti ${ }^{9}$ Iz pisanja Narodnih novina doznaje se i kako su

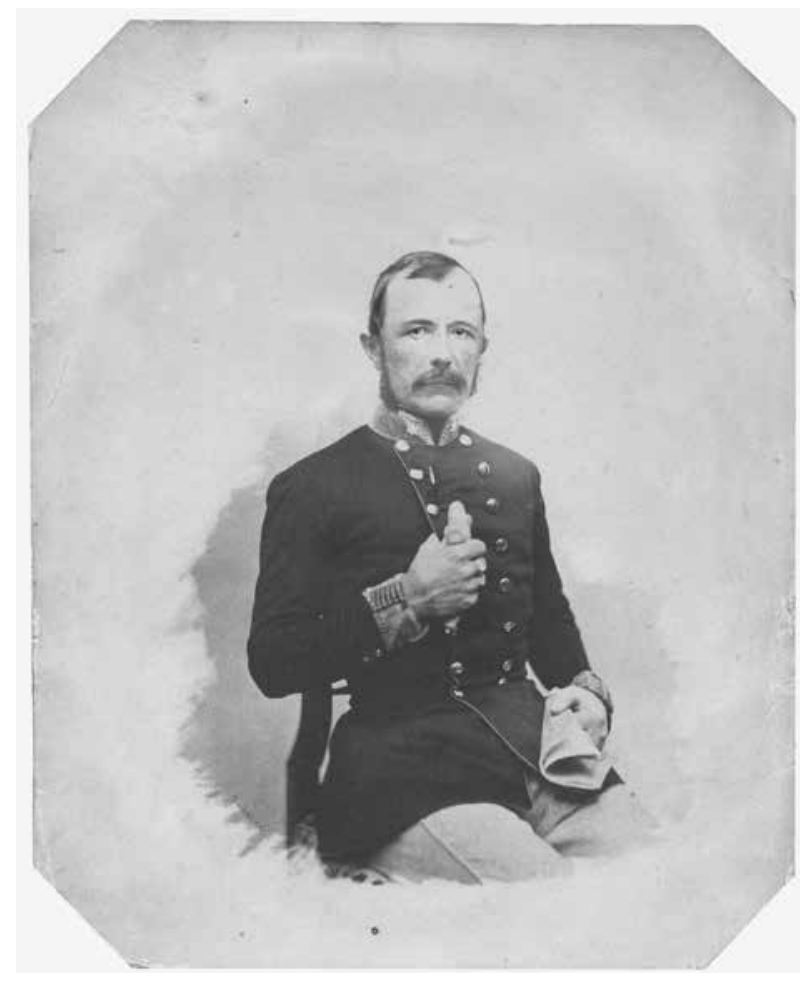

1. Franjo Pommer, Petar Preradović, 1856., slani papir, 20,4× 16,5 cm, Hrvatski državni arhiv, Zagreb (HR-HDA-1443/721) / Franjo Pommer, Petar Preradović, 1856, salted paper, $20.4 \times 16.5 \mathrm{~cm}$, Croatian State Archives, Zagreb (HR-HDA-1443/721)

fotografije bile dostupne u svescima s po tri portretirana pisca i priloženim životopisima, kao i pojedinačno, ${ }^{10}$ a prve su stavljene u prodaju 10. srpnja 1856 . godine. ${ }^{11}$ Cijena po fotografiji iznosila je jedan franak srebra, dok je za svezak bilo potrebno izdvojiti tri franka. ${ }^{12}$

$\mathrm{Na}$ osnovi sačuvanih podataka teško je pouzdano zaključiti je li ideja fotografiranja narodnih spisatelja potekla od samog Pommera ili ga je na to potaknuo netko drugi. Narodne novine pišu kako je Pommer "prionuo na taj posao samo po nagovoru nekih vèrlih prijatelja naše stvari i iz težnje, da bude bar u nečem koristan našemu narodu «. ${ }^{13}$ Na tragu istine možda bi mogao biti Milan Stahuljak koji u svom kratkom osvrtu na Pommerov život i rad piše kako je inicijativa za snimanje albuma pristigla od Ljudevita Gaja i njegova kruga. ${ }^{14}$ Jesu li Gaj i oko njega okupljeni intelektualci uistinu bili vrli prijatelji naše stvari o kojima pišu Narodne novine, teško je sa sigurnošću potvrditi, no činjenica je kako se Pommer, unatoč ograničenim financijskim sredstvima, $\mathrm{u}$ projekt snimanja upustio sam. ${ }^{15}$

Od petnaestorice fotografiranih danas su, prema dostupnim podacima, ostali sačuvani samo portreti trojice književnika, i to Babukića, Preradovića i Kukuljevića, dok je Bogovićev portret poznat jedino iz reprodukcije. Fotografije Vjekoslava Babukića i Ivana Kukuljevića Sakcinskog čuvaju se u Muzeju za umjetnost i obrt u Zagrebu, dok su drugi pri- 


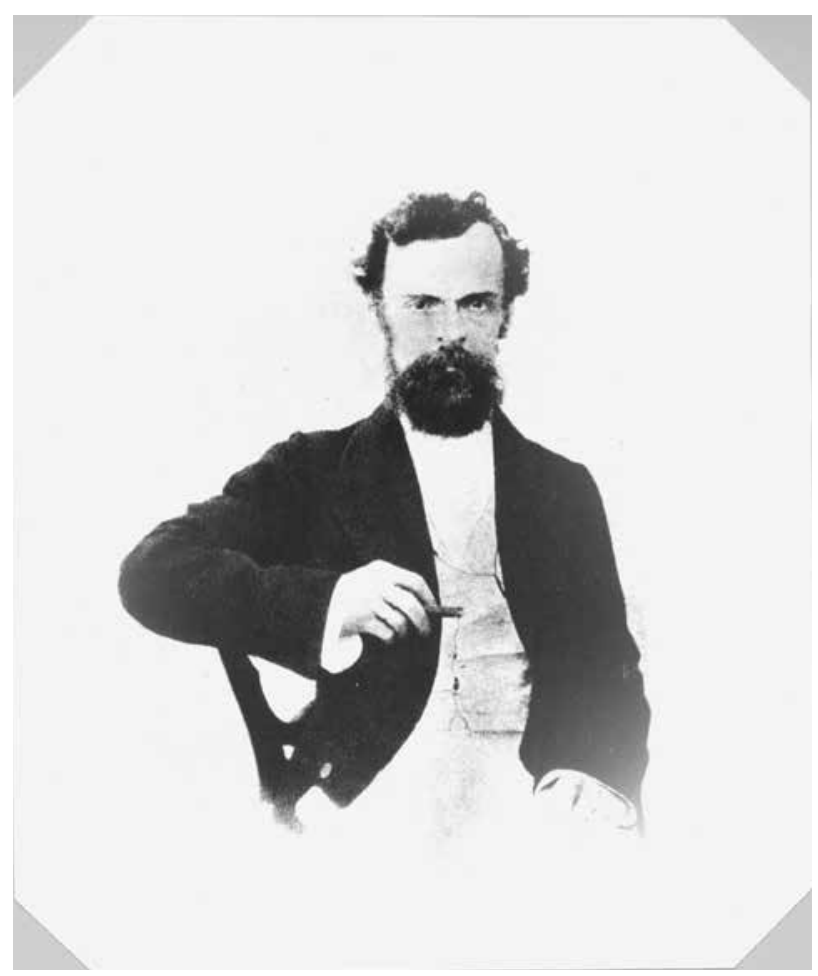

2. Mladen Grčević, Reprodukcija Pommerova portreta Mirka Bogovića, oko 1980., želatinska fotografija, 20,5 × 17,2 cm, Hrvatski državni arhiv, Zagreb / Mladen Grčević, Reproduction of Pommer's Portrait of Mirko Bogović, ca. 1980, gelatin print, $20.5 \times$ $17.2 \mathrm{~cm}$, Croatian State Archives, Zagreb

mjerak Kukuljevićeva portreta te portret Petra Preradovića (sl. 1) pohranjeni u Hrvatskom državnom arhivu u Zagrebu. ${ }^{16}$ Portret Mirka Bogovića prvi je spomenuo Gjuro Szabo 1932. godine u svom tekstu o fotografima starog Zagreba, ${ }^{17}$ a reprodukciju je uspjela pronaći Nada Grčević (sl. 2). ${ }^{18}$

Osim o okončanju snimanja znamenitih hrvatskih književnika i stavljanju fotografija u prodaju, tekst iz Narodnih novina od 11. srpnja 1856. godine iznova donosi podatak $\mathrm{o}$ adresi fotografova ateljea u Vijećničkoj ulici kbr. $10 .{ }^{19} \mathrm{~S}$ ishodištem u toj kratkoj vijesti, u literaturi je zaživio podatak kako je upravo 1856. godina u kojoj je Pommer otvorio svoj zagrebački studio, što je ostalo prisutno u publikacijama do danas. No, kako je vidljivo iz Agramer Zeitunga od 9. svibnja 1854. godine, Pommer - doduše zajedno s Kallainom - tada već djeluje na istoj adresi, ${ }^{20}$ a 1855 . godine Narodne ga novine, izvještavajući o kupnji fotografske opreme i planu izdavanja albuma fotografija narodnih spisatelja, spominju bez partnera. ${ }^{21}$ Slijedom navedenog nameće se pretpostavka kako je Pommer sa samostalnim radom u Zagrebu započeo najkasnije 1855., a možda već i kroz drugu polovinu 1854. godine, čime bi vrijeme otvaranja prvoga zagrebačkog fotografskog ateljea bilo pomaknuto za najmanje godinu dana ranije u odnosu na dosad spominjanu 1856. godinu. ${ }^{22}$

Iz dokumenata pohranjenih u Državnom arhivu u Karlovcu vidljivo je kako je Pommer od 20. prosinca 1854. do
3. siječnja 1855. godine boravio $u$ tom gradu, u kojem je u upisnik stranaca zaveden kao »Daniel Pommer, slikar «. ${ }^{23}$ Taj dragocjeni podatak otkriva i drugo, gotovo nepoznato i rijetko spominjano fotografovo ime, skriveno iza često korištenih inicijala »F. D. Pommer«, otisnutih na brojnim majstorovim fotografijama.

Do kraja 1850-ih godina u tisku će se Pommerovo ime pojaviti još barem jednom, i to 1858. godine, kada Gospodarski list piše kako je Narodni zemaljski muzej poklonom pribavio "fotografičke slike od Pommera, predstavljajuće prizore iz narodnoga života«. ${ }^{24}$ Ova vijest, naslovljena $P o$ kloni za Muzeum, predstavlja prilično rano svjedočanstvo o prikupljanju fotografija u nekom od hrvatskih muzeja, kao i o činjenici da je sam Pommer nakon tek nekoliko godina djelovanja u Zagrebu već bio priznati fotograf koji je svoje snimke poklanjao muzeju.

Idući zabilježeni podatak o Pommerovoj fotografskoj aktivnosti datira iz travnja 1864. godine. Među oglasima Narodnih novina objavljena je kratka obznana kako Pommerov atelje zbog majstorova puta u inozemstvo neće pružati usluge fotografiranja od 1. do 17. svibnja. ${ }^{25}$ Nešto kasnije iste godine spomenut je kao izlagač na Prvoj dalmatinsko-hrvatskoslavonskoj izložbi održanoj u Zagrebu. U katalogu izložbe, među izlagačima unutar IV. reda, XXVIII. podrazreda (Bakrorezi, kamenopisi, svjetlopisi i drvorezi), pod rednim brojem 3433 naveden je »Pommer F. D., iz Zagreba« koji je izložio »svietlopise«. ${ }^{26} \mathrm{Na}$ istoj je izložbi bio i nagrađen, i to »kolajnom za pèrvu nagradu«, kako sam ističe na poleđini svojih fotografija od 1865. godine nadalje, odnosno »srebrnom kolajnom «, kako stoji u popisu odlikovanih, a koju su osim njega na istoj izložbi dobili i fotografi Nathan Hering, Ivan Standl i Petar Zink. ${ }^{27}$ Nakon zagrebačke, Pommer kao izlagač nastupa i na Etnografskoj izložbi u Moskvi otvorenoj 23. travnja 1867. godine, na kojoj njegove fotografije narodnih nošnji također bivaju nagrađene medaljom (»Kaiserl. Russiche medaille«), i to u konkurenciji od 1600 izloženih snimaka. ${ }^{28}$ Vijest o njegovu sudjelovanju na moskovskoj izložbi donosi i Vijenac 1876. godine, ali - najvjerojatnije kao tiskarsku pogrešku - za godinu održavanja navodi 1857. umjesto $1867 .{ }^{29}$ Ovdje vrijedi spomenuti kako je Pommer, osim što je izložio radove, bio i član središnjeg odbora za spomenutu izložbu. ${ }^{30}$ Šezdesetih se godina njegovo ime u tisku spominje još jednom, u veljači 1869. godine, kada na sjednici skupštine Zagrebačkog društva čovječnosti biva izabran u odbor za lutriju. ${ }^{31}$

Od Pommerovih snimaka nastalih tijekom 1860-ih godina ističe se fotografija Odkriće spomenika Jelačića bana u Zagrebu 16. prosinca 1866., danas pohranjena u Muzeju grada Zagreba. ${ }^{32}$ Ova je snimka - jedna od rijetkih sačuvanih Pommerovih fotografija zabilježena izvan ateljea - dugo vremena smatrana prvom hrvatskom reportažnom snimkom. ${ }^{33}$ Nepotpisanu fotografiju Živa zaključna slika iz prologa predstavljena u čast otvorenja visokog sabora 


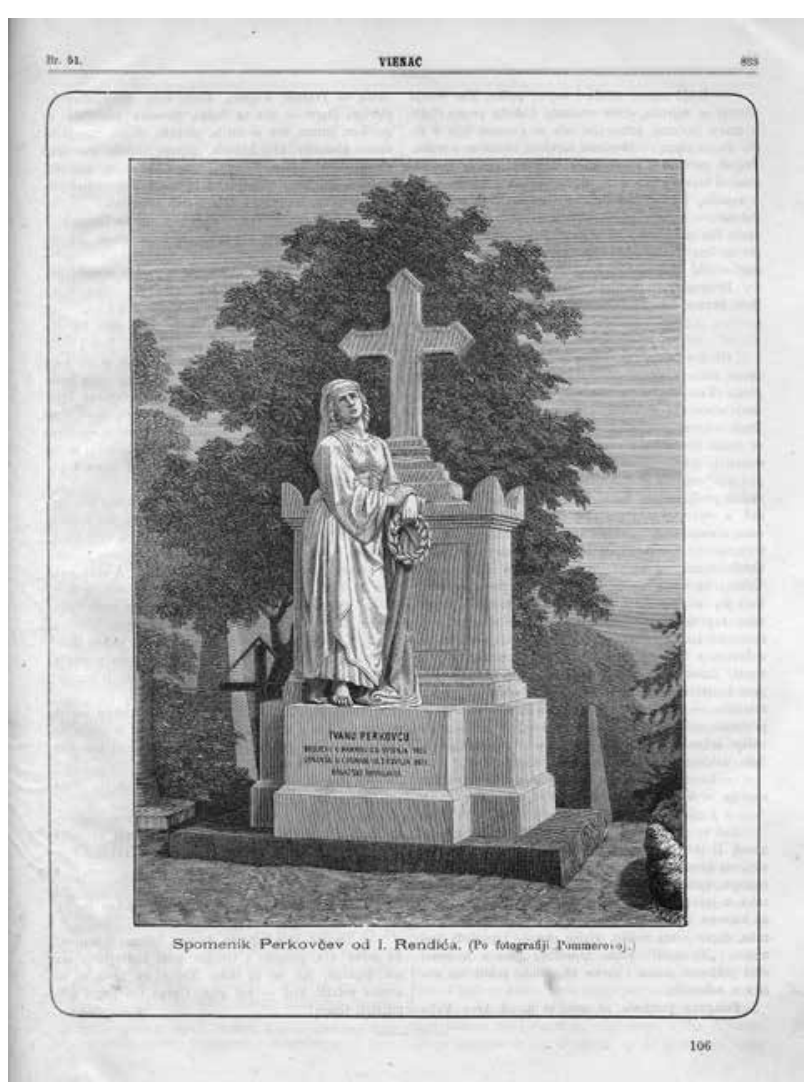

3. Perkovčev spomenik Ivana Rendića, po fotografiji Franje Pommera. Otisak objavljen u listu Vijenac 18. prosinca 1875. / Monument to Perkovac by Ivan Rendić, after a photograph by Franjo Pommer. Published in the Vijenac magazine on 18 December 1875

kraljevinah Dalmacije, Hrvatske i Slavonije, ${ }^{34}$ snimljenu 11. studenoga 1865. godine tijekom izvedbe prologa Jovana Subotića u režiji Josipa Freudenreicha, Marija Tonković pripisuje Pommeru, čime ga uvrštava i među pionire domaće kazališne fotografije. ${ }^{35}$

Nakon dvadeset godina rada $\mathrm{u}$ ateljeu na Gornjem gradu, početkom ožujka 1875. godine Pommer seli u novoizgrađeni atelje u Aleksandrovoj kući u Ilici 732 (danas Ilica 40), u kojem ostaje raditi do smrti. ${ }^{36} \mathrm{U}$ istom ga ateljeu, zaintrigiran primjenom novih stečevina fotografske tehnologije, posjećuje i autor teksta objavljenog u Vijencu 1876. godine, od kojeg doznajemo kako je - tada već u potpunosti afirmirani majstor Pommer, osim komercijalnih portreta, snimao i

4. Franjo Pommer, Portret vojnika (recto i verso), oko 1860., albuminska fotografija, 9,6 × 5,7 cm, Hrvatski državni arhiv, Zagreb (HR-HDA-2018/1) / Franjo Pommer, Portrait of a Soldier (recto and verso), ca. 1860 , albumen print, $9.6 \times 5.7 \mathrm{~cm}$, Croatian State Archives, Zagreb (HR-HDA-2018/1) po nalogu Narodnoga zemaljskog muzeja, a usluge je također pružao i listu Vijenac za njihove ilustracije. ${ }^{37}$ Nešto je ranije $\mathrm{u}$ istoj tiskovini bila objavljena vijest o Pommerovu fotografiranju Rendićeva spomenika Ivanu Perkovcu u Samoboru. ${ }^{38}$ Sliku po navedenoj fotografiji Vijenac je objavio 18. prosinca 1875 . godine (sl. 3), ${ }^{39}$ a moguće je da u nekoj od zbirki u Hrvatskoj postoji i sačuvani izvornik. Franjo Pommer umro je 19. veljače 1879 . godine. ${ }^{40}$

\section{O fotografskom radu}

Pommerov fotografski rad moguće je, sukladno majstorovoj primjeni različitih fotografskih tehnika i opremanju fotografija, podijeliti u nekoliko faza. Fotografije iz ranog razdoblja djelatnosti, snimljene tijekom 1850 -ih godina, obilježava veći format (duža stranica između 15 i $22 \mathrm{~cm}$ ) s ravno odrezanim uglovima ili ovalnog oblika, a nalijepljene su na kartone. Izvedene su u tehnici slanog papira. ${ }^{41}$ Neke od tih ranih primjeraka Pommer je dorađivao ručnim koloriranjem, ${ }^{42}$ a sve su datirane i potpisane na samoj slici autorovim prezimenom i godinom snimanja. U domaćoj ih se literaturi najčešće naziva kalotipijama, mada bi, kako originalni negativi nisu poznati ni sačuvani, prikladnije bilo koristiti termin fotografija na slanom papiru. ${ }^{43}$ Najreprezentativniji primjer ranog razdoblja Pommerove fotografske aktivnosti svakako su sačuvani portreti hrvatskih književnika.

Najviše je sačuvanih Pommerovih fotografija iz razdoblja šezdesetih i početka sedamdesetih godina 19. stoljeća. Riječ je gotovo isključivo o portretima izvedenim na albuminskom papiru $^{44}$ nalijepljenom na kartone formata posjetnice, ${ }^{45}$ na poleđini kojih je moguće pratiti Pommerova odlikovanja i nagrade, te preko opreme samih fotografija približno datirati snimke bez inskripcija. Tako njegove fotografije nastale 

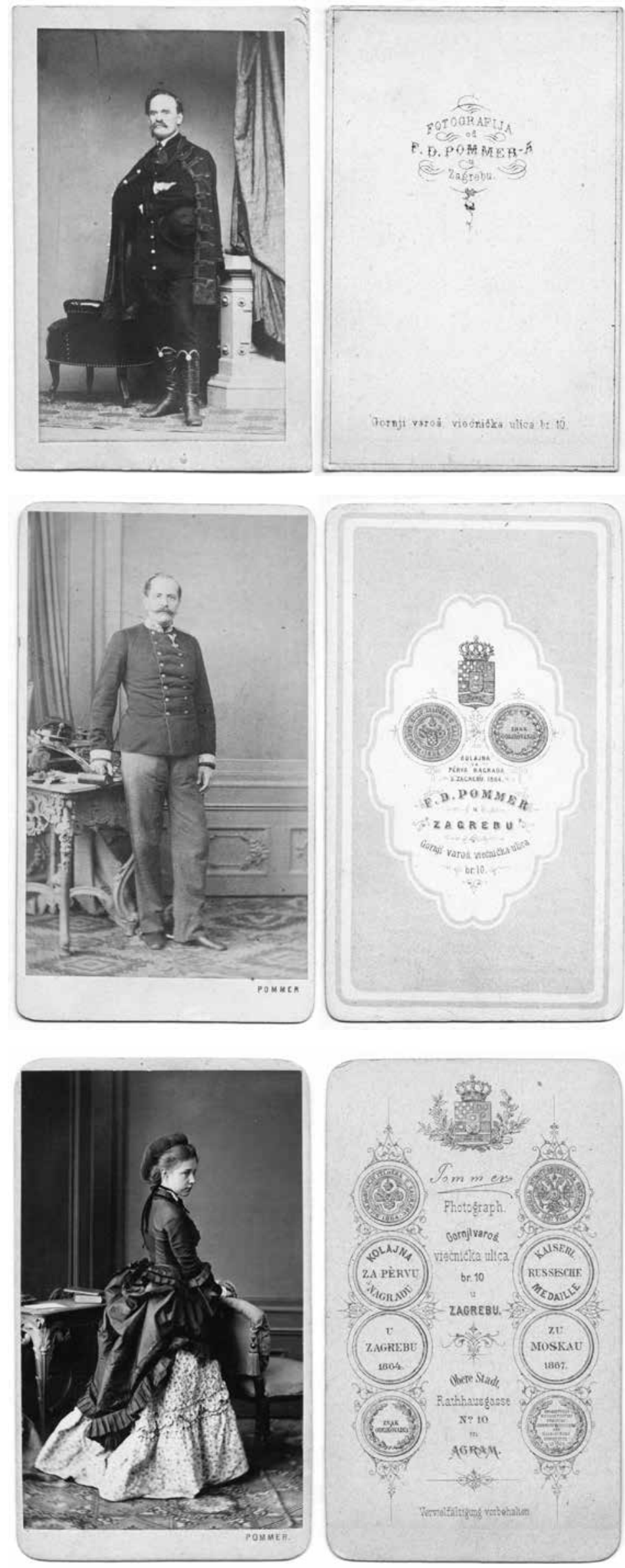
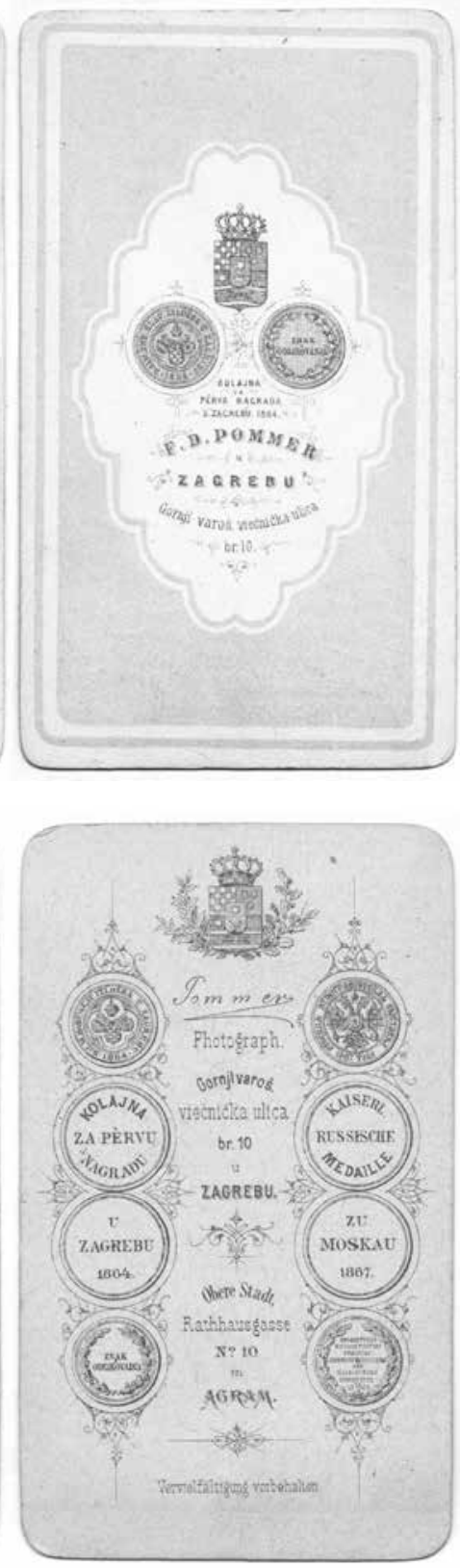

prije zagrebačke izložbe na poleđini imaju samo autorove inicijale i prezime kao i adresu ateljea, $s$ varijacijama u mjestu natpisa i tipografiji te bez ili tek s ponešto stiliziranih ukrasa (sl. 4 i 5). Između 1865. i 1867. godine otisnuta je samo jedna medalja (sl. 6), a nakon moskovske izložbe oba odličja, i taj će se dizajn zadržati do majstorove smrti (sl. 7), uz iznimku promjene adrese po prelasku u novi atelje 1875. godine. Uvođenje fotografija formata posjetnice $u$ Zagreb $u$ literaturi se pripisuje upravo Pommeru, jer neki od sačuvanih primjeraka njegovih fotografija datiraju iz ranih 1860 -ih godina. ${ }^{46}$ Osim po otisnutim nagradama i ornamentima, Pommerove je snimke formata posjetnice moguće razlikovati te približno vremenski odrediti i prema dimenzijama. Dekorativni kartoni s fotografijama ranijeg datuma u pravilu su manjih dimenzija i ravno rezanih uglova, dok su oni kasnijeg nastanka nešto veći i imaju zaobljene uglove.

Novost koju Pommer uvodi tijekom 1870-ih godina jesu fotografije kabinet formata ${ }^{47}$ kao i tzv. nepromjenjive kromotipije, čije se uvođenje otprilike poklapa s preseljenjem u ilički atelje. Unatoč tom novitetu, Pommer istodobno i dalje koristi provjereni albuminski papir, što je vidljivo iz nekih sačuvanih fotografija (sl. 8). ${ }^{48}$ Vrijedan prilog o majstorovu radu u posljednjim godinama života donosi tekst pod naslovom Novi izum na polju fotografije, objavljen u Vijencu od 14. listopada 1876. godine. ${ }^{49}$ Iščitavan sa stajališta današnjeg poznavanja tehničke povijesti fotografije i istraživanja povijesnih fotografskih procesa, izvještaj u Vijencu nije odviše precizan te je u nekim aspektima i potpuno pogrešan, ${ }^{50}$ ali svakako otkriva niz vrijednih detalja. Jednako tako, zanimljivo je

5. Franjo Pommer, Ivan Kukuljević Sakcinski (recto i verso), oko 1862., albuminska fotografija, $9,9 \times 6,3 \mathrm{~cm}$, Hrvatski državni arhiv, Zagreb (HR-HDA-1443/915) / Franjo Pommer, Ivan Kukuljević Sakcinski (recto and verso), ca. 1862, albumen print, $9.9 \times 6.3 \mathrm{~cm}$, Croatian State Archives, Zagreb (HR-HDA-1443/915)

6. Franjo Pommer, General Franjo Filipović (recto $i$ verso), oko 1865., albuminska fotografija, $10,5 \times 6 \mathrm{~cm}$, Hrvatski državni arhiv, Zagreb (HR-HDA-1443/918) / Franjo Pommer, General Franjo Filipović (recto and verso), ca. 1865, albumen print, $10.5 \times 6 \mathrm{~cm}$, Croatian State Archives, Zagreb (HR-HDA-1443/918)

7. Franjo Pommer, Portret djevojke (recto i verso), oko 1875., karbonska fotografija (kromotipija), 10,2 ×6 cm, Hrvatski državni arhiv, Zagreb (HR-HDA-2018/4) / Franjo Pommer, Portrait of a Girl (recto and verso), ca. 1875 , carbon print (chromotype), $10.2 \times 6 \mathrm{~cm}$, Croatian State Archives, Zagreb (HR-HDA-2018/4) 


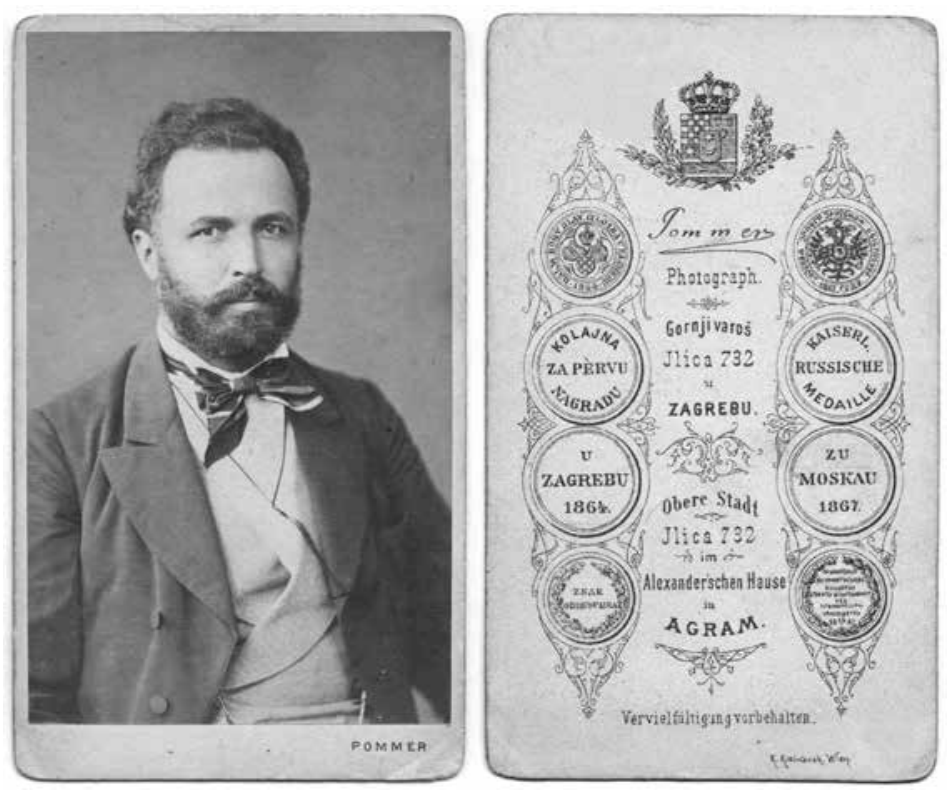

8. Franjo Pommer, Ivan pl. Radić (recto i verso), oko 1875., albuminska fotografija, 10,4 ×6,1 cm, Hrvatski državni arhiv, Zagreb (HRHDA-1443/1127) / Franjo Pommer, Nobleman Ivan Radić (recto and verso), ca. 1875 , albumen print, $10.4 \times 6.1 \mathrm{~cm}$, Croatian State Archives, Zagreb (HRHDA-1443/1127) kako autor u svom napisu vrlo precizno prenosi samu suštinu karbonskog postupka, kojeg naziva "pigment ili ugljenopis«. Riječ je o fotografijama kod kojih je slika dobivena od finih čestica na bazi ugljena ili nekoga drugog pigmenta - kao što autor teksta ispravno primjećuje - koje su raspršene u želatini na papirnoj podlozi. Upravo iz toga razloga sama slika ne pokazuje znakove oštećenja ni promjene te nalikuje tek izrađenoj albuminskoj fotografiji bez kemijskih oštećenja. ${ }^{51}$ Takve Pommerove fotografije ponekad na dekorativnom kartonu ispod slike nose natpis »Nepromienive chromotipije« (sl. 9), ${ }^{52}$ a sačuvane su u formatima posjetnice te $\mathrm{u}$ kabinet formatu. ${ }^{53}$ Kao što je vidljivo, kromotipije također spominje autor teksta u Vijencu, ali u potpuno drugom kontekstu, povezujući ih s ručno koloriranim fotografijama. Iz napisanog ostaje nejasno je li Pommer svoje karbonske fotografije ponekad naknadno dorađivao ručnim nanošenjem boje, kao što je činio sa snimkama na slanom papiru ili albuminskim fotografijama. Dosadašnjim uvidom u zbirke fotografija na području Zagreba takve, naime, nisu pronađene. Moguće je također kako je autor teksta u Vijencu poistovjetio ručno kolorirane fotografije s pojmom kromotipija povezanim uz karbonski postupak. Kako bilo da bilo, kao sigurna ostaje činjenica da je sredinom 1870-ih godina, dok u Zagrebu i Hrvatskoj pri izradi pozitiva dominira albuminski postupak, Pommer Zagrepčanima mogao ponuditi i karbonske fotografije (kromotipije). ${ }^{54}$

\section{Zaključni osvrt}

Franjo Daniel Pommer, rođenjem Danac, kao fotograf je u Zagrebu neprekidno radio od 1854. do smrti 1879. godine, o čemu svjedoči više napisa u onodobnom tisku. Kroz spomenuto je razdoblje njegov atelje promijenio tek dvije adrese - onu u Vijećničkoj ulici 10 te Ilici 732. Upravo je Pommerov gornjogradski atelje, u današnjoj Kuševićevoj ulici, najstariji zagrebački fotografski studio, otvaranje kojeg je pouzdano moguće datirati najkasnije u 1854. godinu. Te se godine, u svibnju mjesecu, Pommer prvi put spominje kao suvlasnik spomenutog ateljea kojeg vodi zajedno s Josephom Kallainom. Nakon kratke karlovačke epizode, osobito dragocjene poradi činjenice da je omogućila otkrivanje fo-

9. Franjo Pommer, Portret svećenika, oko 1875., karbonska fotografija (kromotipija), 16,7 × 11,1 cm, Hrvatski državni arhiv, Zagreb (HR-HDA-1443/487) / Franjo Pommer, Portrait of a Priest, ca. 1875 , carbon print (chromotype), $16.7 \times 11.1 \mathrm{~cm}$, Croatian State Archives, Zagreb (HR-HDA-1443/487) 
tografova srednjeg imena, Pommer godine 1855. kao samostalni obrtnik privlači pozornost kulturne javnosti snimajući istaknute hrvatske književnike, čije je fotografske portrete namjeravao istoj ponuditi na prodaju. Spomenuti podatak pokazao je kako gornjogradski atelje u tom trenutku više nema suvlasnika, nego u njemu radi samo Pommer, čime je kao terminus post quem non otvaranja prvoga zagrebačkog fotografskog ateljea moguće, umjesto dosad spominjane 1856., uzeti prethodnu godinu. Također, ne treba odbaciti ni mogućnost da je već tijekom druge polovine 1854 . godine Pommer u istom ateljeu radio samostalno.

Nakon što je njegov opus magnum s portretima hrvatskih književnika bio dovršen, majstor se gotovo posve okrenuo svakodnevnom studijskom radu, o čemu svjedoče brojne sačuvane portretne fotografije. Brzo se afirmiravši u društvu, tijekom 1860-ih godina Pommer osvaja i dvije nagrade za svoj fotografski rad, da bi u posljednjem razdoblju, nekoliko godina prije smrti, Zagrepčanima ponudio novi fotografski postupak: kromotipije odnosno karbonske fotografije. $\mathrm{Bu}-$ dući da ih nije sačuvano mnogo, širinu upotrebe i vrijeme uvođenja novog postupka u Pommerov atelje moguće je tek orisati. No, zahvaljujući osvrtu u Vijencu ostaje činjenica kako je javnost za spomenutu inovaciju bila itekako zainteresirana.

Promatrana sa stajališta fotografske tehnologije i procesa izrade snimaka, Pommerova je djelatnost za potrebe ovog rada podijeljena u tri faze: prvu, tijekom 1850-ih, koju karakteriziraju nešto veći formati snimaka na slanom papiru, zatim drugu, zrelu, gotovo u potpunosti obilježenu albuminskim fotografijama formata posjetnice te kasnu, koja se približno poklapa s prelaskom u novi atelje i traje do smrti, a tijekom koje uvodi i snimke kabinet formata te spomenute karbonske fotografije ili kromotipije.

Ovaj je rad na jednom mjestu okupio dosad poznate činjenice o životu i radu proga zagrebačkog rezidentnog fotografskog majstora te ih dopunio novim saznanjima, temeljenim na pregledu mnoštva sačuvanih fotografija, nešto arhivskog gradiva te pisanja onodobnih novina. Tako izložen i dopunjen životni i profesionalni put Franje Pommera trebao bi biti na pomoć pri daljem istraživačkom radu, posebice onom vezanom uz majstorove fotografije koje u trenutku pisanja ovog rada nisu bile poznate, a zasigurno postoje sačuvane u zbirkama po Zagrebu, Hrvatskoj, a možda i šire.

\section{BILJEŠKE}

1 NADA GRČEVIĆ, Fotografija devetnaestog stoljeća u Hrvatskoj, Društvo povjesničara umjetnosti Hrvatske, Zagreb, 1981., 223.

2 Vlastoručnim potpisom »F. D. Pommer, decorateur« završava popis ukrasnih elemenata u kazalištu naslovljen Decorationen-Verzeichniss über vorhandene Decorationen (Popis postojećih dekoracija) od 27. svibnja 1852. godine. Hrvatski državni arhiv (dalje: HDA), Fond br. 893 , Gradivo o kazališnoj djelatnosti u Zagrebu, kutija 5. O Pommerovu ra- du u kazalištu piše i Milan Stahuljak, a kao izvor navodi kazališne spise: „Uprava kazališta ga pozva da kao $>$ kazališni bojadisar i i (slikar) izrađuje i popravlja dekoracije. U kazališnim spisima Pommer iza vlastoručnog potpisa dodaje zanimanje sdecorateur . Iz th spisa razabiremo da je Pommer dobro poznavao ne samo razvitak kazališta i kazališnu tehniku, nego da je bio i risarski (slikarski) >meštar $s$ istančanim ukusom, a to su uvjeti za valjana fotografa.« MILAN STAHULJAK, Franjo Pommer prvi zagrebački fotograf, Naša fotografija, 5-6 (1950.), 17.

3 »Den Kunstfreunden diene es zur Nachricht, das bei den Photographen HH. J. Kallain und J. Pommer das gelungene Portrait der Primadonna Fel. Kammerer als Norma zu bekommen ist. Auch Jedermann, dem es daran liegt, sein eigenes naturgetreues Conterfei um den bifligsten Preis anfertigen zu lassen, inviiren wir auf das Atelier der HH. Kallain \& Pommer in der Magistratsrathsgasse Nr. 10.« Agramer Zeitung, br. 106 (9. 5. 1854.).

4 »U Zagrebu. Doznajemo iz pouzdana izvora, da ovdiešnji risar, g. F. D. Pommer, namierava putem predplate izdati >Album`, gdie će topografirani biti svi izvèrstnii naši književnici. Tih slikah bit će, kako čujemo, do 15 na broju, a svakoj pojedinoj slici dodat će se životopis dotičnog književnika. Mi unapred gojimo podpunu nadu, da će hvalevriedno nastojanje i domorodna nakana vieštoga našega umietnika naći odziva i svake podpore u našega rodoljubivog obćinstva. U svoje vrieme izjavit će se pobližji uvjeti predplate i onda kanimo još koju rieč o tom poduzeću progovoriti.« Carsko-kr. službene narodne novine, br. 184 (11. 8. 1855.).

5 »Zasad samo mimogred spominjemo, da je g. Pommer za taj posao jur si nabavio osobiti stroj fotografički, što ga sastavi Weingartshofen u Döblingu kod Beča. Ovaj stroj mnogo stoji novacah, što nam i opet dokazuje, da g. Pommer misli zbilja niešto izvèrstnoga izdati.« Carsko-kr. službene narodne novine (bilj. 4).

6 NADA GRČEVIĆ (bilj. 1), 32, 223.

7 Austrian photographic products: Lenses, URL: http://www.photohistory.at/objektive1.htm (12. 2. 2014.).

8 SIMON WEBER-UNGER (ur.), Der naturwissenschlaftliche Blick: Fotografie, Zeichung und Modell im 19. Jahrehundert, Wissenschaftliches Kabinett Simon Weber-Unger, Wien, 2009., 71.

9 Carsko-kr. službene narodne novine, br. 153 (4. 7. 1856.).

10 »Umietnik će izdavati te slike u svescima. Svaki svezak obsizat će tri slike na velikom foliu a tomu bit će pridodan na posebnom listu kratki životopis svakog pojedinog, kojeg će napisati ovih danah koje viešto pero. Pèrvi svezak izać će do petnaest danah. Da si te slike svatko laglje nabavi, to je umietnik namislio prodavati takodjer svaku napose.« Carsko-kr. službene narodne novine (bilj. 9).

11 »Fotografične slike naših narodnih spisateljah mogu se od jučer kupiti u knjigarnici g. Hartmana u dugoj ulici i kod samog izdatelja fotografa F. D. Pommera u gornjoj varoši, viećničkoj ulici, kućni br. 10.« Carsko-kr. službene narodne novine, br. 159 (11. 7. 1856.).

12 "Ciena nije zaista prevelika za toli vèrstno dielo; svaka će slika stojati samo 1. fr. a ravno tako svezak 3 fr « - Carsko-kr. službene narodne novine (bilj. 9).

13 Carsko-kr. službene narodne novine (bilj. 9).

14 »Tada dr. Ljudevit Gaj i drugi sklonu našega ^risara da fotografski snimi tadašnje istaknute kulturne radnike i izda Album. "MILAN STAHULJAK (bilj. 2), 18.

15 »Ufamo se dakle, da će ovo poduzetje naći kod našeg obćinstva i kod drugih austrijskih Slavenah dovoljno odziva i podpore, da se umietniku trošak ako i ne trud naplati pa da mu se sredstvo poda, da i dalje nastavi svoju radnju, koja će nama biti na ponos i veselje.« Carsko-kr. službene narodne novine (bilj. 9).

16 Vjekoslav Babukić (Inv. br. MUO 5625), Ivan Kukuljević Sakcinski (Inv. br. MUO 7339 i HDA, Fond br. 738), Petar Preradović (HDA, Fond br. 1443/721).

$17 »$ Die älteste signierte Porträtaufnahme aus Zagreb, die mir bisher bekannt geworden, ist eine Bildnisstudie des Illyrers Mirko Bogović aus dem Jahr 1856, hergestellt von F. D. Pommer. Es ist eine vollendet schöne Aufnahme, leider kaum reproduzierbar, da das Papier schwer stockfleckig geworden." GJURO SZABO, Altzagaber Meisterphotographen, Morgenblatt, br. 352 (24. 12. 1932.), 9. 
18 NADA GRČEVIĆ (bilj. 1), 33-34.

19 Carsko-kr. službene narodne novine (bilj. 11).

20 Vidi bilješku 3.

21 Vidi bilješke 4 i 5 .

22 Time bi Pommerov zagrebački atelje bio približni suvremenik onom zadarskog ljekarnika Josipa Brčića, otvorenom također najkasnije 1855. godine. ABDULAH SEFEROVIĆ, Photographia Iadertina. Od dagerotipije do digitalne slike, Kapitol, Zagreb, 2009., 21, 369.

23 SANDA KOČEVAR, Iz starih albuma: karlovački fotografi (18501940) iz fundusa Gradskog muzeja Karlovac, Gradski muzej Karlovac, Karlovac, 2002., 10.

24 Gospodarski list, br. 14 (8. 4. 1858.), 72.

25 »Podpisani uzimlje si čast štovanomu obćinstvu u i izvan Zagreba do znanja staviti, da se u njegovom ateliru u viećničkoj ulici kuće br. 10. radi poduzetja poslovnog puta od 1 . do 17 . svibnja t. g. fotografiranje poduzimati neće. - U Zagrebu, 26. travnja 1864. F. D. Pommer, fotograf.« Narodne novine, br. 99 (30. 4. 1864.).

26 Prva dalmatinsko-hrvatsko-slavonska izložba u Zagrebu, katalog izložbe, Zagreb, 1864., 238.

27 Album uspomenica na prvu dalmatinsko-slavonsko-hrvatsku izložbu plodinah, tvorinah $i$ umjetninah u Zagrebu god. 1864, Zagreb, 1864., 116. Popis odlikovanih također u: Narodne novine, br. 236 (15. 10. 1864.).

28 The First Ethnographic Exhibition, URL: http://eng.ethnomuseum. $\mathrm{ru} /$ section62/349/887/2277.htm (15. 3. 2014.).

29 Vienac, br. 42 (14. 10. 1876.), 696.

30 Narodne novine, br. 216 (20. 9. 1866.) i Narodne novine, br. 219 (24. 9. 1866.).

31 Narodne novine, br. 28 (5. 2. 1869.).

32 Muzej grada Zagreba, inv. br. MGZ 8660.

33 NADA GRČEVIĆ (bilj. 1), 47; MARIJA TONKOVIĆ, Oris povijesti fotografije u Hrvatskoj, u: Fotografija u Hrvatskoj 1848-1950, katalog izložbe, (ur.) Vladimir Maleković, Muzej za umjetnost i obrt, Zagreb, 20. 9. - 20. 11. 1994., 46-173.

34 Izvorna se snimka čuva u Knjižnici Hrvatske akademije znanosti i umjetnosti. JOSIP FREUDENREICH, Prolog: slika u 1 čin : predstavljen prigodom svečane predstave $u$ čast otvorenja Sabora Trojedine kraljevine Dalmacije, Hrvatske i Slavonije dne 11. studenoga 1865. S krasnom fotografijom "žive zaključne slike" / izdao za uspomenu i svoj gospodi sabornikom u smiernosti posvetio Josip Freudenreich, redatelj, Zagreb, 1865.

35 MARIJA TONKOVIĆ, Pretpovijest reportažne fotografije u Hrvatskoj, Život umjetnosti, 74-75 (2005.), 116.

36 »Otvaraj umjetničke djelaonice. Podpisani javlja uljudno štovanom obćinstvu u i izvan Zagreba, da je u Aleksandrovoj kući, Ilica br. 732. otvorio početkom o. m. svoj na novo sazidani atelier za snimanje portraitâ svake veličine. F. D. Pommer« - Obzor, br. 69 (26. 3. 1875.). Milan Stahuljak, doduše, u svom tekstu o Pommeru piše sljedeće: "Kad je Pommer primijetio da Donji grad polagano preuzima vodstvo u Zagrebu, seli iz Gornjeg grada u Ilicu, gdje god. 1862. iznenađuje Zagrepčane s novopodignutim sjajnim ,glassalonom $<$, a novine sve više ističu usavršavanje njegovih slika.« (MILAN STAHULJAK (bilj. 2), 18), no napisi u onodobnim novinama i sačuvane fotografije navedeno opovrgavaju, jer na njima uz adresu Vijećnička kbr. 10 stoje medalje s izložbi iz 1864. i 1867. godine.

37 »Desiv se ovih dana u atelieru gospodina Pommera (u Ilici u Aleksandrovoj kući, kraj brzojavnog ureda) vidjesmo (...) i fotografije nedavno izkopanih zlatnih srpskih novaca, koje je g. Pommer vanrednom oštrinom i preciznosti izveo po nalogu narodnog zem. muzeja. (...) Gospodin Pommer, rodom Danac, prvi je u Zagrebu pred mnogo godina osnovao stalni fotografski atelier, našemu listu bio je vrlo često na uslugu pri snimanju domaćih predmeta za naše ilustracije« - Vienac (bilj. 29), 696.

38 "Zagrebački svjetlopisac g. Pommer snimio je za naš list Perkovčev spomenik u Samoboru, te ćemo ga skoro donieti. Izim toga sgotovio je g. Pommer poveći broj tih svjetlopisa u vizitnom i kabinetskom formatu, te si mogu rodoljubi hrvatski za jeftinu cienu nabaviti snimak Rendićeva umotvora, koj će se za kratko moći dobiti u kr. sveučilišnoj knjižari
Albrechta i Fiedlera. Mi te svjetlopise tim toplije preporučamo obćinstvu, jer je g. Pommer namienio četvrtinu nečista prihoda tih svjetlopisa još ne pokrivenu trošku za spomenik i ne možemo nego javno zahvalit mu se za taj rodoljubivi čin.«Vienac, br. 45 (6. 11. 1875.), 732.

39 Vienac, br. 51 (18. 12. 1875.), 833.

40 MILAN STAHULJAK (bilj. 2), 18; NADA GRČEVIĆ (bilj. 1), 51.

41 Fotografija na slanom papiru pozitiv je izveden iz negativa kontaktnim kopiranjem pod sunčevim svjetlom. Podloga je običan pisaći papir na koji je najprije nanesena otopina natrijeva klorida (kuhinjska sol, od koje dolazi i naziv slani papir, op. a.), a zatim je senzibiliziran u otopini srebrnog nitrata. Tako pripremljeni papir trebalo je u kraćem vremenu upotrijebiti, pa su obično pripremani neposredno prije izrade fotografija. Nakon eksponiranja, slika je fiksirana u natrijevu tiosulfatu, a nerijetko je proces uključivao i toniranje zlatom, nakon čega je fotografija ispirana i sušena. Karakterizira ih mat površina i slika toplog tona. BERTRAND LAVÉDRINE, Photographs of the Past: Process and Preservation, Getty Conservation Institute, Los Angeles, 2009., 104-109.

42 Neki od primjeraka ručno koloriranih Pommerovih snimaka na slanom papiru čuvaju se u Muzeju za umjetnost i obrt u Zagrebu: Tri djevojčice, 1856. (Inv. br. MUO 21916), Petar Preradović, 1857. (Inv. br. MUO 18181).

43 Termin kalotipija danas se u literaturi koristi gotovo isključivo za negativ fazu Talbotova fotografskog postupka patentiranog 1841. godine. - BERTRAND LAVÉDRINE (bilj. 41), 224-231, 321; ANNE CARTIERBRESSON (ur.), Le vocabulaire technique de la photographie, Marval, Pariz, 2008., 72-75. U slučaju kada nije sačuvan negativ, a isti bi osim kalotipije, odnosno negativa na papiru u to vrijeme mogao biti i mokra kolodijska ploča, preciznije je pozitiv određivati prema samoj tehnici izvedbe, što je u ovom slučaju slani papir. Čak bi i naziv kalotipijski pozitiv, koji bi upućivao na činjenicu kako je pozitiv izrađen iz kalotipije odnosno neke od njezinih modifikacija, bio neprecizan sve dok nije moguće pouzdano ustvrditi kakve je negative autor koristio.

44 Albuminski fotopapir u upotrebu je 1850. godine uveo Louis-Désiré Blanquart-Evrard, a u upotrebi se zadržao gotovo kroz cijelo 19. stoljeće. Albuminski papir izrađivan je natapanjem jedne strane običnog papira $\mathrm{u}$ otopini tučenog bjelanjka jajeta (albumin) i natrijeva klorida, nakon čega bi se papir sušio te senzibilizirao u otopini srebrnog nitrata. Tako pripremljen bio je spreman za upotrebu. Fotografije su dobivane iz negativa kontaktnim kopiranjem pod sunčevim svjetlom. BERTRAND LAVÉDRINE (bilj. 41), 112-123.

45 Fotografije formata posjetnice (engl. carte-de-visite ili skraćeno CDV) u upotrebu je 1854. godine uveo francuski fotograf André Adolphe Eugène Disdéri, i tijekom idućeg su desetljeća postale prevladavajući format u portretnoj fotografiji. Raniji primjerci gotovo su isključivo izvedeni na albuminskom papiru, dok je kasnije moguće naći i karbonskih, kolodijskih te želatinskih fotografija. Zajednička im je značajka ukrasni karton približnih dimenzija $11 \times 6 \mathrm{~cm}$ na koji je fotografija nalijepljena, a na kojem su otisnuti podaci o fotografu te, u slučaju da je bio nagrađivan, osvojene nagrade i odlikovanja. GORDON BALDWIN, MARTIN JÜRGENS, Looking at Photographs: A Guide To Technical Terms, Getty Publications, Los Angeles, 2009., 14.

46 NADA GRČEVIĆ (bilj. 1), 41; DUBRAVKA OSREČKI JAKELIĆ, Fotografija u vrijeme historicizma, u: Historicizam u Hrvatskoj, sv. I, katalog izložbe, Muzej za umjetnost i obrt, Zagreb, 17. 2. - 28. 5. 2000., 420-429.

47 Fotografije kabinet formata u upotrebu je uveo škotski fotograf George Washington Wilson 1862. godine. Riječ je o fotografijama nalijepljenima na kartone približne veličine $16 \times 11 \mathrm{~cm}$. Kao i kod formata posjetnice, fotografije mogu biti albuminske, kolodijske, želatinske ili karbonske, a dekorirane su također ornamentima, nagradama i informacijama o fotografu. - GORDON BALDWIN, MARTIN JÜRGENS (bilj. 45), 7. Pommerove »svjetlopise u kabinetskom formatu « spominje i autor teksta u Vijencu govoreći o fotografijama spomenika Ivanu Perkovcu (vidi bilj. 38).

48 Kao primjer ostala je sačuvana fotografija Ivana pl. Radića koja na poleđini nosi adresu ateljea iz Ilice 732. Fotografija se čuva u Hrvatskom državnom arhivu u Zagrebu (HDA, Fond br. 1443/1127).

49 "U novije vrijeme velik je napredak učinjen na polju fotografije tim, što se je iznašao način, kako će fotografije ostati nepromjenljive i trajne. 
Novi taj način jest tako zvani pigment ili ugljenopis. Desiv se ovih dana u atelieru gospodina Pommera (u Ilici u Aleksandrovoj kući, kraj brzojavnog ureda) vidjesmo više takovih slika (...). Osim ove nepromjenljivosti ovakve su fotografije vanredno mekane u tonovih i shvatljive za najmanje potankosti. - Osim toga vidjesmo i više portreta sa naravnimi bojami, takozvane chromotypije. Dakako da te fotografije nisu izravno sa bojami snimljene, - do toga problema još nije došla umjetnost fotografijska; nu na snimljenu fotogafiju apliciraju se kašnje boje i nadat se je, da će ovaj način doskora obćinstvu omiliti. (...) Sada nam je drago, da je on i opet prvi, koj nam nove stečevine na tom polju u Zagreb donosi, tako da za drugimi ne zaostajemo."Vienac, br. 42 (14. 10. 1876.), 696.

50 Iz izvještaja je razvidno kako autor teksta nije upoznat s pionirskim istraživanjima na polju fotografije u boji koja su Edmond Becquerel, Abel Niépce de Saint-Victor, Levi Hill, James Clerk Maxwell te Louis Ducos du Hauron odvojeno provodili između 1848. i 1868. godine. Više o spomenutim istraživanjima u: BERTRAND LAVÉDRINE (bilj. 41), 40-47, 202-203.

51 Više o karbonskim fotografijama u: BERTRAND LAVÉDRINE (bilj. 41), 164-169; ANNE CARTIER-BRESSON (bilj. 43), 156-157.
52 Kromotipije, kao modifikaciju osnovnoga karbonskog procesa, uveo je i patentom zaštitio 1875. godine Claude Leon Lambert u Engleskoj, a sljedećih su se godina proširile po Škotskoj, Irskoj, Sjedinjenim Američkim Državama i Kanadi. - JOHN WERGE, The Evolution of Photography, London, 1890., 98. Nije potvrđeno je li Pommer platio pravo na korištenje Lambertova patenta, no ostaje činjenica kako je uvođenjem kromotipija pratio novotarije na području fotografske tehnike i s neznatnim ih zakašnjenjem uvodio u Zagreb i Hrvatsku, što je i isticao stavljanjem spomenutog natpisa na dekorativni karton ispod fotografije.

53 Kod pronađenih kromotipija formata posjetnice na prednjoj strani ukrasnog kartona ispod fotografije ponekad je otisnut tekst »NEPROMIENIVE CHROMOTIPIJE«, a ponekad toga teksta nema, dok je na poleđini uvijek vidljiva dekoracija $s$ adresom ateljea (bilo gornjogradskog ili novog u Ilici). U slučaju sačuvanih kabinet formata, ispod fotografije na kartonu uvijek stoji »F. D. POMMER - NEPROMIENIVE CHROMOTIPIJE - AGRAM.«, ali je poleđina prazna.

54 Tu činjenicu možda najbolje oslikava Nada Grčević zaključujući kako je »samo renomirani majstor kakav je bio Pommer mogao uvesti ınove stečevine i priviknuti općinstvo na njih.« NADA GRČEVIĆ (bilj. 1), 46.

\section{Summary}

Hrvoje Gržina

New Findings on the Life and Work of Franjo Pommer, the First Resident Photographer in Zagreb

In the history of Croatian photography Franjo Pommer is documented not only on account of the quality of his photographic work, but also for being Zagreb's first resident photographer. His Upper Town studio located in today's Kuševićeva Street was the oldest photographic studio in Zagreb, active from 1854 at the latest. In May of the said year Pommer is recorded as its owner alongside photographer Joseph Kallain, while the following year the local press mentioned him as an independent artisan who photographed distinguished Croatian writers, whose photo portraits accompanied by their biographies Pommer planned to offer for sale to the Croatian public. The said news report dated August 1855 represents the terminus post quem non for the opening of the first photographic studio in Zagreb, although there is a possibility of Pommer's autonomous activity in the same studio already during the second half of 1854 . Due to the high quality of his photographs and his continuing interest for the novelties in the field of photographic technology, over the following two and $a$ half decades Pommer earned the status of one of the most distinguished photographers in Zagreb, a reputation he would maintain until his death in 1879. Pommer's photographic activity in Zagreb can be divided in three phases: the first, datable in the 1850s, is characterized by large-format prints on salted paper; the second, mature phase is distinguished by the prevalence of albumen prints of carte-de-viste format, and finally the third, late phase roughly corresponds to the period from his relocation to a new studio until his death, during which he introduced cabinet-format photographs and carbon prints or chromotypes. In the present article the author precisely defines photographic processes used in the master's work through the analysis of preserved prints and through the use of contemporary photography terminology. 
